\title{
Yield Stability in Winter Wheat Production: A Survey on German Farmers' and Advisors' Views
}

\author{
Janna Macholdt * and Bernd Honermeier \\ Department of Agronomy, Institute of Agronomy and Plant Breeding I, Justus-Liebig-University Giessen, \\ 35392 Giessen, Germany; bernd.honermeier@agrar.uni-giessen.de \\ * Correspondence: janna.c.macholdt@agrar.uni-giessen.de; Tel.: +49-641-99-37441
}

Academic Editors: Mamoru Okamoto, Darren Plett and Trevor Garnett Received: 8 May 2017; Accepted: 22 June 2017; Published: 26 June 2017

\begin{abstract}
Most of the available research studies have focused on the production of high grain yields of wheat and have neglected yield stability. However, yield stability is a relevant factor in agronomic practice and, therefore, is the focus of this comprehensive survey. The aim was to first describe the importance of yield stability as well as currently used practical management strategies that ensure yield stability in wheat production and secondly, to obtain potential research areas supporting yield stability in the complex system of agronomy. The target groups were German farmers with experience in wheat production and advisors with expertise in the field of wheat cultivation or research. A sample size of 615 completed questionnaires formed the data basis of this study. The study itself provides evidence that the yield stability of winter wheat is even more important than the amount of yield for a large proportion of farmers ( $48 \%$ ) and advisors $(47 \%)$. Furthermore, in the view of the majority of the surveyed farmers and advisors, yield stability is gaining importance in climate change. Data analysis showed that site adapted cultivar choice, favorable crop rotations and integrated plant protection are ranked as three of the most important agronomic management practices to achieve high yield stability of wheat. Soil tillage and fertilization occupied a middle position, whereas sowing date and sowing density were estimated with lower importance. However, yield stability is affected by many environmental, genetic and agronomic factors, which subsequently makes it a complex matter. Hence, yield stability in farming practice must be analyzed and improved in a systems approach.
\end{abstract}

Keywords: advisor; agronomy; agronomic practice; climate change; cultivar choice; environment; farmer; plant production

\section{Introduction}

In Germany, winter wheat is the main cereal crop grown on 3.2 million hectares ( $54 \%$ of the cereal production area), which is nearly one third of the arable land [1]. With an average yield of $7.7 \mathrm{t} \mathrm{ha}^{-1}$ in 2016, the total grain production of wheat was 24.6 million tons [2]. Due to the enormous economic significance and high crop share of wheat on farms, achieving high grain yields in German wheat production is very important. With a particular regard to climate change, the focus may shift from only targeting high grain yields to also focusing on yield stability. The driving forces for this change are due to environmentally-forced growing conditions, such as the incidence of early summer drought, late frost or torrential rainfall [3]. These future climatic changes and increasing climatic variability are already scientifically proven within specific scenarios for German field conditions [4,5]. Outside of Germany, an increasing demand of yield stable wheat cultivars that are adapted to climate change has been observed [6-8]. However, recent German studies suggest a special and enhanced interest from farmers in improving yield stability of wheat cultivars [9-11]. Apart from cultivar selection, there are currently no empirical studies focusing on yield stability in a systems approach taking different agronomic management factors into account. 
Agronomic treatments can affect the yield stability of winter wheat significantly. For example, nitrogen fertilization based on plant needs and applied in both mineral or organic form can be assumed as one main treatment in improving yield stability [12-14]. Furthermore, crop rotations with a higher share of cereals show a negative impact on yield stability of winter wheat, especially for wheat monocultures. In contrast, diverse crop rotations with favorable preceding crops (e.g., legumes) affect the yield stability of the main crop winter wheat positively [15-19]. Beyond that, cultivar choice is an effective tool in farming practice, which is used to support yield stable wheat production $[3,12,20]$. In particular, a higher yield and enhanced yield stability have been found for hybrid cultivars in comparison to inbred lines of wheat [9].

Nevertheless, breeding and analyzing the yield stability of wheat cultivars is a difficult and complex task [7]. There are two approaches for measuring yield stability: static and dynamic [21]. According to the static approach, the yield amount should not vary across environments or agronomic treatments for high yield stability. This method may be helpful for evaluating genetically fixed characteristics of cultivars, such as special resistances, but it does not fit well in agronomic practice as wheat plants have the potential to make use of favorable growing conditions and can translate them into enhanced yield or better quality. This issue is considered in the dynamic approach where, for example, a high stability is assumed only at the cultivar level if the marginal yield deviation from the general response of cultivars to agronomic treatments or environmental conditions is shown by a cultivar [22].

Despite yield stability of winter wheat being a relevant issue in agronomic practice, most of the available research studies are only focusing on targeting high grain yields of wheat and neglecting yield stability. Thus, information on the yield stability in German wheat cultivation is currently limited and fragmented. Furthermore, only experimental results (e.g., from field trials) are commonly used in agronomic research, with survey approaches scarcely applied. Against this background, this comprehensive survey was to take a step towards closing this gap. The aim was to first describe the importance of yield stability as well as currently used practical management strategies that ensure yield stability in wheat production and secondly, to derive potential research areas supporting yield stability in the complex system of agronomy. Based on the views of farmers with experience in practical wheat production and advisors with expertise in the field of wheat cultivation or research, the major objective of this study was to answer the following questions:

(1) How important is the yield stability compared to yield amount of winter wheat?

(2) Which agronomic management practices are estimated to improve yield stability of winter wheat?

(3) What kind of cultivars or variety types of winter wheat provide higher yield stability?

\section{Results}

\subsection{Importance of Yield Stability in Wheat Production}

The first question considered what farmers and advisors understood as the idea of yield stability. To narrow this definition, the respondents were asked to decide between the static and dynamic concept of stability (Table 1). A detailed explanation of the two stability concepts was provided next to the question. The majority of farmers (58\%) and advisors (72\%) approved the dynamic concept of stability. In comparison, selections of static concept were low and around $10-11 \%$ abstained from answering this question. Furthermore, farmers were asked how important yield stability is in their wheat production and advisors were asked how important yield stability is for the farmers they advise (Table 2). A majority of farmers stated that yield stability was very important (57\%). Advisors showed similar perceptions. None of the respondents stated a low importance of yield stability $(0 \%)$, whereas only a small part abstained. In this context, the respondents assessed the importance of yield stability in comparison to the yield amount of winter wheat (Table 3). Nearly half of the farmers and advisors considered that the yield stability was more important than amount of yield. Only a small part negated this. Additionally, $41 \%$ of respondents estimated an equal importance of yield stability and yield 
amount. Interestingly, there was a significant correlation $(R=0.71 ; p<0.05)$ between the frequency of spring/early summer drought stated by farmers and their high demand of yield stable wheat cultivars. A second significant correlation $(R=0.65 ; p<0.05)$ was calculated for the association between soil quality and farmers' evaluations of the importance of yield stability. A lower soil quality on their own farmland resulted in farmers assigning a higher importance to yield stability in their wheat production.

Table 1. Farmers' and advisors' approvals for either the static or dynamic concept of yield stability.

\begin{tabular}{ccc}
\hline Response Option & Farmers $^{\mathbf{1}} \mathbf{( \% )}$ & Advisors $^{\mathbf{2}} \mathbf{( \% )}$ \\
\hline Static concept & 31 & 18 \\
Dynamic concept & 58 & 72 \\
Not specified & 11 & 10 \\
\hline \multicolumn{2}{c}{$n=474 ;^{2} n=141}$.
\end{tabular}

Table 2. Farmers' and advisors' evaluations of the importance of yield stability in wheat production.

\begin{tabular}{ccc}
\hline Response Option & Farmers $^{\mathbf{1}} \mathbf{( \% )}$ & Advisors $^{\mathbf{2}} \mathbf{( \% )}$ \\
\hline Very high & 57 & 60 \\
High & 32 & 32 \\
Intermediate & 9 & 0 \\
Low & 0 & 0 \\
Not specified & 2 & 8 \\
\hline & ${ }^{1} n=474 ;^{2} n=141$.
\end{tabular}

Table 3. Farmers' and advisors' estimations of whether yield stability was more important than yield amount of winter wheat.

\begin{tabular}{ccc}
\hline Response Option & Farmers $^{\mathbf{1}} \mathbf{( \% )}$ & Advisors $^{\mathbf{2}} \mathbf{( \% )}$ \\
\hline Higher importance & 48 & 47 \\
Equal importance & 41 & 42 \\
Lower importance & 6 & 1 \\
Not specified & 5 & 10 \\
\hline \multicolumn{2}{c}{$n=474 ;^{2} n=141}$.
\end{tabular}

\subsection{Effect of Agronomic Management Practices on Stability of Wheat Yields}

Agronomic management practices can have a positive impact on the yield stability of winter wheat. The interviewed farmers and advisors evaluated nine different management practices based on a four-point Likert rating scale (very high, high, intermediate and low). In this study, farmers assessed cultivar choice, crop rotation and plant protection as the three most important management practices that affected yield stability (Table 4). Mineral fertilization and soil cultivation were assigned as having moderate effects. In comparison, sowing date, organic fertilization and sowing density were assigned as having only minor effects by the farmers. Irrigation seemed to be a special issue where $34 \%$ of farmers abstained. This topic might be not relevant nationwide, but for a few farmers, it was of high $(8 \%)$ or very high importance $(9 \%)$. Additionally, farmers added comments about their own experience and evaluated partly methods actually practiced on their farm. Farmers $(n=92)$ commented in the free text fields that plant breeding was assumed by them to be the most promising approach for improving yield stability of winter wheat. Several farmers $(n=49)$ underlined in the free text field the relevance of sufficient and well-balanced macro- and micro-nutrient supply (N, P, K, S, Mn, Cu, Bor and Zn) for yield stable wheat production. Additionally, comments from farmers $(n=23)$ about sowing date were made where the positive effects on yield stability could only be assumed if the sowing date was adapted to site conditions and wheat cultivar. 
Table 4. Farmer evaluation of the positive impact of different agronomic management practices on yield stability of winter wheat $(n=474)$.

\begin{tabular}{cccccc}
\hline Response Option & Very High (\%) & High (\%) & Intermediate (\%) & Low (\%) & Not Specified (\%) \\
\hline Cultivar choice & 52 & 35 & 2 & 0 & 11 \\
Crop rotation & 49 & 36 & 4 & 0 & 11 \\
Plant protection & 46 & 36 & 5 & 0 & 12 \\
Mineral fertilization & 37 & 41 & 9 & 1 & 12 \\
Soil cultivation & 36 & 41 & 11 & 0 & 12 \\
Sowing date & 22 & 42 & 23 & 1 & 12 \\
Organic fertilization & 19 & 33 & 26 & 8 & 14 \\
Sowing density & 17 & 42 & 28 & 3 & 10 \\
Irrigation & 9 & 8 & 22 & 27 & 34 \\
\hline
\end{tabular}

Advisors ranked the management practices in a similar way, with only slight differences in the hierarchy (Table 5). Similar to farmers, advisors evaluated cultivar choice, crop rotation and plant protection as the three most important management practices affecting the yield stability of wheat, while soil cultivation, mineral fertilization and sowing date were also ranked as having moderate effects. This was closely followed by sowing density, organic fertilization and irrigation in subordinated ranks. For irrigation, many abstentions $(70 \%)$ were noted. The only difference between farmers and advisors was that advisors $(70 \%)$ evaluated very high impact positive of cultivar choice more frequently than farmers $(52 \%)$. Furthermore, in the free text fields, advisors $(n=72)$ underlined an application of the integrated plant protection approach based on the control threshold principle and finding the right application date. They also mentioned the relevance of monitoring systems, biological plant protection methods and preventive measures (e.g., favorable crop rotations). Additionally, several advisors $(n=63)$ highlighted in the free text fields the importance of straw manure for soil fertility and increasing humus content in the soil, especially with regards to climate change adaptation.

Table 5. Advisor evaluation of the positive impact of different agronomic management practices on yield stability of winter wheat $(n=141)$.

\begin{tabular}{cccccc}
\hline Response Option & Very High (\%) & High (\%) & Intermediate (\%) & Low (\%) & Not Specified (\%) \\
\hline Cultivar choice & 70 & 21 & 1 & 0 & 8 \\
Crop rotation & 55 & 30 & 6 & 1 & 8 \\
Plant protection & 44 & 43 & 4 & 0 & 9 \\
Soil cultivation & 38 & 48 & 6 & 1 & 7 \\
Mineral fertilization & 33 & 45 & 13 & 1 & 8 \\
Sowing date & 26 & 44 & 21 & 1 & 8 \\
Sowing density & 21 & 35 & 36 & 4 & 7 \\
Organic fertilization & 21 & 34 & 33 & 6 & 70 \\
Irrigation & 4 & 12 & 8 &
\end{tabular}

Furthermore, farmers and advisors were asked if they assumed any effects of different soil cultivation systems on yield stability in wheat production (Table 6). Nearly half of the farmers were of the view that ploughing (conventional system) and soil conservation systems with deep soil cultivation could improve yield stability. They commented in free text fields that ploughing would have advantages in terms of preventing plant health and reducing weed pressure. In contrast, extensive systems, such as shallow conservative cultivation (33\%) or no-till farming (55\%), seemed to have negative effects that could lead to more unstable wheat yields. Around one third of farmers took a neutral position and stated that there was no effect of ploughing (conventional) or conservative soil cultivation systems on the yield stability of wheat. Overall, a higher number of farmers (16-22\%) abstained from this question. 
Table 6. Farmer evaluation to the effects of different soil cultivation systems on yield stability of winter wheat $(n=474)$.

\begin{tabular}{ccccc}
\hline Response Option & $\begin{array}{c}\text { Positive } \\
(\mathbf{\%})\end{array}$ & $\begin{array}{c}\text { Neutral } \\
\mathbf{( \% )}\end{array}$ & $\begin{array}{c}\text { Negative } \\
\mathbf{( \% )}\end{array}$ & $\begin{array}{c}\text { Not Specified } \\
\mathbf{( \% )}\end{array}$ \\
\hline Ploughing (conventional system) & 50 & 29 & 5 & 16 \\
Soil conservation system (intensive, deep) & 45 & 32 & 7 & 16 \\
Soil conservation system (extensive, shallow) & 14 & 35 & 33 & 18 \\
No-till system & 5 & 18 & 55 & 22 \\
\hline
\end{tabular}

Furthermore, there was a strong relation between farmers' evaluations to the positive effects of different soil cultivation systems on yield stability of winter wheat and the used soil cultivation system on their own farm (Table 7), especially for farmers practicing ploughing (conventional system) or no-till systems. Furthermore, one quarter of farmers working with soil conservation systems also stated that no-till systems have positive effects on yield stability of winter wheat. In addition, $17 \%$ of famers practicing ploughing estimated a positive effect of soil conservation system (intensive) on yield stability. The low number of respondents in the column of no-till systems $(n=24)$ has to be noted.

Table 7. Cross table for the participant group 'farmers' with actual use of soil cultivation system in practice and evaluation to the positive effects of different soil cultivation systems on yield stability of winter wheat.

\begin{tabular}{|c|c|c|c|c|}
\hline \multirow[b]{2}{*}{$\begin{array}{l}\text { Actual Use of Soil Cultivation } \\
\text { System in Practice }\end{array}$} & \multicolumn{4}{|c|}{ Estimation of Positive Effects on Yield Stability of Winter Wheat } \\
\hline & $\begin{array}{c}\text { Ploughing } \\
\text { (Conventional) } \\
(\%)^{1}\end{array}$ & $\begin{array}{c}\text { Soil Conservation } \\
\text { System (Intensive) } \\
\left(_{(\%)^{2}}\right.\end{array}$ & $\begin{array}{c}\text { Soil Conservation } \\
\text { System (Extensive) } \\
(\%)^{3}\end{array}$ & $\begin{array}{c}\text { No-Till } \\
\text { System } \\
(\%)^{4}\end{array}$ \\
\hline Ploughing (conventional system) $(n=224)$ & 95 & 17 & 6 & 0 \\
\hline Soil conservation system $(n=229)$ & 5 & 82 & 91 & 25 \\
\hline No-till system $(n=21)$ & 0 & 1 & 3 & 75 \\
\hline
\end{tabular}

Advisors evaluated the effects of different soil cultivation systems with nearly the same tendencies as farmers (Table 8). Ploughing (conventional system) was ranked first as the best variant for stable wheat yields. The soil conservation system with intensive and deep soil cultivation was ranked second with positive $(32 \%)$ or rather neutral effects $(51 \%)$ on yield stability. On the other hand, advisors indicated adverse effects for extensive variants of soil conservation systems (shallow, extensive), which was especially high for no-till farming. However, around $30 \%$ of advisors also stated neutral effects on yield stability for these two reduced soil cultivation systems.

Table 8. Advisor evaluation to the effects of different soil cultivation systems on yield stability of winter wheat $(n=141)$.

\begin{tabular}{ccccc}
\hline Response Option & $\begin{array}{c}\text { Positive } \\
\mathbf{( \% )}\end{array}$ & $\begin{array}{c}\text { Neutral } \\
\mathbf{( \% )}\end{array}$ & $\begin{array}{c}\text { Negative } \\
\mathbf{( \% )}\end{array}$ & $\begin{array}{c}\text { Not Specified } \\
\mathbf{( \% )}\end{array}$ \\
\hline Ploughing (conventional system) & 59 & 18 & 2 & 21 \\
Soil conservation system (intensive, deep) & 32 & 51 & 4 & 13 \\
Soil conservation system (extensive, shallow) & 13 & 31 & 43 & 13 \\
No-till system & 13 & 28 & 50 & 9 \\
\hline
\end{tabular}

\subsection{Comparison of Cultivar Types}

Cultivar choice is a very important tool in cereal production and can have positive effects on the yield stability of winter wheat. In practice, farmers can choose between two types: hybrid or line cultivars. In this study (Table 9), 10\% of the farmers interviewed attributed use of hybrid cultivars to a 
higher yield stability; $24 \%$ of farmers declared a similar yield stability for both types; and $12 \%$ stated a lower yield stability for hybrids in comparison to line cultivars. Comparatively, the estimations of the advisors were relatively equal: $9 \%$ of advisors assumed higher yield stability for hybrids; $3 \%$ voted against it; and 13\% estimated similar yield stability for hybrid and line cultivars. Overall, more than half of the respondents ( $54 \%$ farmers, $75 \%$ advisors) abstained from this question. Interestingly, there were significant correlations of soil quality $(R=0.67, p<0.05)$ and high frequency of early summer drought $(R=0.51, p<0.05)$ stated by farmers with farmers' evaluations regarding yield stability of hybrids versus lines. Thus, a higher frequency of drought stress or better soil quality of sites on which farmers are cultivating wheat resulted in farmers more frequently stating a similar or even higher yield stability of hybrids compared to line cultivars. In that context, some farmers commented in the free text fields that cultivating hybrid wheat cultivars in poor soil appeared to not be appropriate, because hybrids would only develop their full yield potential on soils with good quality (German Ackerzahl above 60 points). Thus, in their experience, advantages in grain yield and better yield stability of hybrids compared to lines could not be seen in low-yielding sites. Furthermore, several farmers and advisors stated that in their opinion, hybrids seem to have a higher drought tolerance due to better vitality, greater rooting system and water uptake efficiency, when compared to line cultivars of winter wheat.

Table 9. Farmers' and advisors' evaluations regarding yield stability of hybrids compared to line cultivars of winter wheat.

\begin{tabular}{ccc}
\hline Response Option & Farmers $^{\mathbf{1}} \mathbf{( \% )}$ & Advisors $^{\mathbf{2}} \mathbf{( \% )}$ \\
\hline Higher & 10 & 9 \\
Similar & 24 & 13 \\
Lower & 12 & 3 \\
Not specified & 54 & 75 \\
\hline \multicolumn{3}{c}{$n=474 ;^{2} n=141}$.
\end{tabular}

Breeding of wheat cultivars for adapting to current and future environmental conditions is progressing further. However, whether newly developed and registered cultivars offered higher yield stability in comparison to previously bred and registered cultivars was answered by farmers and advisors as shown in Table 10. Nearly half of the farmers and advisors estimated that new cultivars had a higher yield stability in practice farming, although $15 \%$ of farmers and $23 \%$ of advisors argued against it. An equal stability level for new and older cultivars was stated by almost $30 \%$ of respondents. A relatively small number of respondents abstained (11\% or $9 \%)$.

Table 10. Farmers' and advisors' estimations if newly registered wheat cultivars have higher yield stability in comparison to prior registered cultivars.

\begin{tabular}{ccc}
\hline Response Option & Farmers $^{\mathbf{1}} \mathbf{( \% )}$ & Advisors $^{\mathbf{2}} \mathbf{( \% )}$ \\
\hline Yes & 45 & 40 \\
No & 15 & 23 \\
Equal & 29 & 28 \\
Not specified & 11 & 9 \\
\hline \multicolumn{3}{c}{}
\end{tabular}

With climate change, the yield stability of wheat cultivars has become more important in farming practice. This view was taken by $67 \%$ of farmers and $50 \%$ of advisors who were interviewed in this study (Table 11), with only a small percentage (4-6\%) of respondents denying it. A further $16 \%$ of farmers and $36 \%$ of advisors were undecided on this issue. In comparison to farmers, the respondent group of advisors had a smaller number of proponents and a higher number of waverers. The percentage of abstention was $13 \%$ for farmers and $8 \%$ for advisors. Additionally, there 
was a significant positive correlation $(R=0.61 ; p<0.05)$ of the occurrence of drought stress during spring/early summer stated by farmers with farmers' perceptions that yield stability of wheat cultivars will become more important with climate change.

Table 11. Farmers' and advisors' perceptions if yield stability of wheat cultivars will become more important with climate change.

\begin{tabular}{ccc}
\hline Response Option & Farmers $^{\mathbf{1}} \mathbf{( \% )}$ & Advisors $^{\mathbf{2}} \mathbf{( \% )}$ \\
\hline Yes & 67 & 50 \\
No & 4 & 6 \\
Perhaps & 16 & 36 \\
Not specified & 13 & 8 \\
\hline \multicolumn{3}{c}{}
\end{tabular}

Overall, for advisors and farmers, no correlations between acreage of winter wheat, experience in wheat production (years) or region and their responses to the asked questions in this study could be determined. Furthermore, no associations between various responses of farmers/advisors between different set of questions were found, except a positive correlation of farmers' $(R=63 ; p<0.05)$ and advisors' $(R=0.59 ; p<0.05)$ evaluations of importance of yield stability with their perceptions of whether yield stability of wheat cultivars will gain in importance with climate change.

\section{Discussion}

Although this study is not based on experimental data, the appraisals of farmers and advisors (experts) are offering very precious and compact information based on their long-term experience in wheat production. In particular, as there are only few experimental studies about yield stability carried out so far, the outcome of this study can be seen as a comprehensive and reliable empirical estimation about the positive impact of different agronomic management practices on yield stability of winter wheat. Knowing well that the studies' approach is quite unique and relatively unconventional in the area of agronomy, the presented results might serve as a basis for scientific discussions and help to derive further research needs.

The majority of farmers and advisors surveyed estimated the yield stability of winter wheat as very important. More than half of the respondents stated that yield stability was more important than yield amount. Certainly, if yield stability is great and yield amount is low, this is inadequate and not meant by farmers. Instead, farmers stated a demand for favorable combinations of high yield stability and high yield amount and with this combination, the respondents put greater weighting on yield stability. These findings are in line with recent studies carried out previously [3]. Thus, risk management, such as a high yield stability of winter wheat, is of high importance. A possible explanation could be the relevance of yield stability for wheat production, especially with regards to the negative consequences of climate change, including more frequent early summer droughts, heavy rainfall events and late frosts caused by climate change [23,24]. Furthermore, climate change will also cause increased biotic stress pressure due to changes in the appearance of pests and diseases, which will also affect the yield variability of wheat negatively [25]. Against this background, the respondents in this study commented in the free text field that plant health, disease resistance, water use efficiency, drought tolerance and heat tolerance were the relevant properties with regards to yield stable wheat production under changing climatic conditions. One further explanation for the high importance of yield stability may be that farmers have to rely on good and stable yield performance in wheat production, especially with regard to increasing economic pressure, market fluctuations and wheat price volatility. Increasing market volatility will lead to insecurity and financial risks for farmers [26].

In this study, cultivar choice, crop rotation and plant protection were ranked as the three most important agronomic management tools for improving yield stability of winter wheat, followed by mineral fertilization and soil tillage. These estimations are consistent with recent findings of 
Rial-Lovera et al. [20] and Eitzinger et al. [27]. Additionally, the work of Rozbicki et al. [28] and Bilgin et al. [29] described that the yield stability of winter wheat was subject to complex interaction between the cultivar and other environmental factors, such as nitrogen supply, rainfall, temperature and soil fertility. Based on the European study of Olesen et al. [30], farmers are currently adapting to climate change by changing the timing of cultivation in addition to selecting other crop species and cultivars. Furthermore, farmers showed a high proportion of negative expectations (drought, heat stress, risk from plant pathogens/pests, higher weed occurrence, new weed species) concerning the impact of climate change on wheat and wheat production throughout Europe [30].

\subsection{Cultivar Choice and Plant Breeding}

Site adapted cultivar choice can be assumed as the basis for high and stable wheat yields. In this study, the respondents rated cultivar choice as the most important agronomic management decision in wheat production. Additionally, several respondents argued that plant breeding was assumed as the most promising approach to improve yield stability of winter wheat. The high importance of cultivar choice and plant breeding was congruent with findings from related studies $[3,8,20]$. Plant breeding has led to an increased yield potential for wheat through increasing the harvest index, radiation interception and its use efficiency in the plants in addition to interactions between nitrogen, phosphorous and carbon dynamics [31]. Laidig et al. [32] stated that most of the positive yield progress of winter wheat over the last 30 years in Germany was generated mainly by genetic improvements, with the contribution of other agronomic factors having been of lower importance. Based on the re-analysis of official variety trials of the United Kingdom over the period 1948-2007 for winter wheat, at least $88 \%$ of the improvement in grain yield can be attributed to genetic improvement, with only $12 \%$ ascribed to changes in agronomy [33]. For the period 1983-2014, a large gain in grain yield of winter wheat in official variety trials (24\%) and on farms (32\%) was achieved in Germany [34]. Additionally, a slight increase in better yield stability of newer wheat cultivars has been found retrospectively based on the analysis of German official variety trials from 1983-2014 [34]. This effect was also mentioned by nearly half of the respondents in this study (Table 10). However, this issue was not clear in agronomic practice as one third of farmers and advisors surveyed did not notice a better yield stability of newer wheat cultivars. Thus, further breeding focused on the environmental stability of wheat cultivars, an exploration into the sources of grain yield variations in addition to qualitative and quantitative trend evaluation of yield stability for winter wheat still require further study. Oritz et al. [35] suggested breeding programs to improve both the above-mentioned factors simultaneously using a combined index based on stability parameters and grain yield. Thus, the out-yielders that exhibited a low coefficient of phenotypic variation should be selected within a broad-based wheat breeding pool.

Cultivar choice also implies the selection of a special variety type whether they are from hybrids or inbred lines. At present, $97 \%$ of wheat cultivars registered in Germany are line varieties and are grown predominantly in German wheat production, with only $3 \%$ being hybrids [36]. Due to the heterosis effect, wheat hybrids can offer higher yield potential, better stress tolerance (especially drought tolerance), increased root capacity and better health compared to inbred lines [37]. The studies of Mühleisen et al. [9] and Longing et al. [38] verified that wheat hybrids were more yield stable than inbred lines on average. This result seems promising and beneficial for agronomic practice, especially with increasing abiotic stresses due to climate change. The scientific results are in line with personal statements made by several farmers and advisors surveyed. In their practical experience, hybrids seem to have a higher drought tolerance due to better vitality, greater rooting system and water uptake efficiency, when compared to line cultivars of winter wheat. However, as already mentioned, hybrids are not very common in German agronomic practice. This was also seen in the high number of abstentions (both farmers and advisors) within this study (Table 9) where there was no widespread, comprehensive and long-term experience with hybrids. Thus, a valid assessment of the better yield stability of wheat hybrids when compared to inbred lines was only possible for a small part of the respondents ( $10 \%$ of farmers and $9 \%$ of advisors). Interestingly, farmers surveyed stated 
that advantages in grain yield and yield stability of hybrids compared to lines were mainly seen on high-yielding sites with better soil quality. Therefore, specific multi-environmental studies about the yield stability of hybrid wheat cultivars depending on soil quality would be necessary. In the future, perhaps more wheat hybrids will be with their advantages possibly becoming stronger and approved in farming practice with further breeding progress, which may lead to an increased wheat cultivation area with hybrids.

With regard to climate change, the selection of wheat cultivars with a high adaption potential to environmental stresses by farmers was expected to gain in importance [30]. This study came to a similar conclusion as the surveyed farmers and advisors stated that yield stability of wheat cultivars will come to the forefront as a result of climate change. In this context, respondents frequently mentioned the properties of efficient water use, drought tolerance, heat tolerance and plant health/disease resistance. This clearly shows that the yield stability of wheat cultivars is a complex issue and remains a great challenge for implementation in plant breeding. Apart from the yield and quality of wheat, the ability to adjust to changing environmental conditions, ability to compete against weeds as well as pest and disease resistance will increase in importance [39]. The climatic factors that the winter wheat cultivars have the greatest sensitivities to are the summer rainfall and winter temperature [33]. Thus, drought tolerance in the case of early summer drought, resistance to lodging in heavy rainfall events and winter hardiness are very important properties that should be considered in cultivar choice in terms of climate change. This study showed a strong and significant correlation of the occurrence of drought stress during spring and early summer stated by farmers with their high demand of yield stable wheat cultivars. Advisors from a regional research center of agriculture with special experience in drought impact on sandy sites recommended principally the wheat cultivars with a lower tendency to tillering because wheat plants with a high number of tillers often led to significant yield losses under drought stress. Yield advantages under the impact of drought in spring and early summer can be expected by cultivars with a better vitality and an intensified growth, especially root growth, in autumn. Thus, these plants are providing a better rooting system, which allows them to be able to reach available soil water in deeper soil layers during drought stress in spring and early summer. Some farmers surveyed mentioned (in free text fields) a good experience in an early summer drought with wheat cultivars that tend to have a rapid yield development and subsequent earlier grain maturity. These farmers also stated that on dry sites, later maturing cultivars are not able to use the longer vegetation period for implementing higher yields. Furthermore, several farmers and advisors commented on the advantages of cultivars with long-stalk straw regarding higher yield stability due to a positive correlation between stalk and root length. Unfortunately, there are no scientific studies about the correlation between these cultivar characteristics and long-term yield stability of winter wheat. Possibly, further investigations are needed to clarify these issues.

\subsection{Crop Rotation}

In this study, crop rotations were assumed to have the second greatest effects on the yield stability of crop production systems. The high importance of crop rotations is consistent with the findings of several scientific studies. Favorable, diverse and lengthened crop rotations can improve yield stability of winter wheat. On the other hand, monocultures of wheat lead to enhanced yield variations [15,40,41]. Favorable preceding crops, such as oilseed rape and legumes (e.g., peas and field beans), can positively affect the yield stability of winter wheat as the subsequent maincrop [16,17]. Furthermore, crop rotations can break soil pathogen cycles and reduce weedpressure [42]. In the context of crop rotations, farmers also mentioned in the additional free text fields the advantages of cultivating catch crops for the yield stability of winter wheat production. Surveyed advisors stated the increased importance of favorable crop rotations with regards to the current restrictions on mineral fertilization, the amendment of German governmental fertilization regulations [43] and further prohibition of several active ingredients in chemical plant protection products due to the German Plant Protection Act [44]. Overall, crop rotations should not only be planned for monetarily 
driven factors, but also with regards to soil fertility and environmental sustainability. Therefore, crop rotations should be seen as a systems approach. Some of the respondents stated that favorable crop rotations could react as a buffer for plants in the event of environmental stresses, which could assist in improving yield stability in crop production. However, further investigation is needed to evaluate the effect of different crop rotations on the yield stability of winter wheat under varying environments or agronomic treatments. Optimally, these would be analyses with long-term field trials.

\subsection{Plant Protection}

For the surveyed farmers and advisors, plant protection was ranked third highest in importance for yield stable wheat production. Plant health is a decisive criterion to secure wheat yields through reducing biotic stresses (e.g., weeds, pests and pathogens). Furthermore, a longer period of photosynthetic active green leaf area has been suggested as the main factor for yield increases obtained with strobilurin and triazole fungicides as the increased photosynthetic period increases the quantity of assimilate available for grain filling [45]. Moreover, as Mercer and Ruddock [46] observed, the application of chemical growth regulators could improve root capacities, while a wide range of fungicides led to a retention of green leaf area of wheat plants. Overall, as stated by Loyce et al. [47], cultivar adapted plant protection is very important as there is a significant interaction effect between the cultivar and the application of fungicides.

At present, major changes in the plant protection schemes due to regulatory reductions in the use of chemical plant protection products are expected [44]. The respondents in this study underlined an application of the integrated plant protection approach based on the control threshold principle and selecting the right application date. They also mentioned the relevance of biological plant protection methods and preventive measures (e.g., favorable crop rotations) in terms of the increasing absence of chemical plant protection products (German Plant Protection Act) and resistance management. In this context, the importance of plant protection and monitoring systems was underlined by a large number of farmers and advisors. This is consistent with related studies, which emphasized the need for pest and disease monitoring as a key adaptation response to climate change [30]. Additionally, many farmers requested the breeding of multi-resistant wheat cultivars. In this context, Loyce et al. [31] observed a synergistic effect between growing multi-resistant cultivars and low-input management systems (lower amount of seeds, mineral fertilizers, fungicides and growth regulators) where each made the other more profitable. The results demonstrated the potential benefits of using low-input crop management systems with cultivars displaying multiple resistances to diseases and lodging. In terms of sustainability and the preservation of natural resources, this aspect should be considered in plant breeding where new cultivars need to be evaluated under a range of environmental and agronomic treatment conditions as well as their adaptation to high- and low-input systems.

A further aspect of integrated plant protection is growing mixtures of cultivars. Diseases could be reduced by growing mixtures of cultivars with different resistance genes, which could result in greater yield stability when compared with pure stands [39]. The different cultivars in the mixtures also react differently to biotic and abiotic stresses. Cultivar mixtures compensate for variations in environmental conditions such as drought and therefore limit the risks of yield loss. Due to the interactions among the different components, mixtures provide a buffer against environmental variations. The complementary effect of cultivar mixtures includes the loss of inoculum due to the presence of resistant plants between susceptible ones and resistance induced by avirulentpathogens [48]. Furthermore, cultivar mixtures provide control against airborne diseases, enabling fungicide treatment to be delayed or reduced [49]. In plant breeding, intra-crop diversity is pursued and reached through the inclusion of functional genetic diversity for diseases, pests and abiotic stress resistances into new wheat cultivars. This could help improve yield stability in wheat production in addition to breeding crops adapted to mixed cropping. 


\subsection{Soil Cultivation}

Wheat farmers may expect yield amount and yield stability improvements through reduced soil or even no-till cultivation as well as appropriate rotations and retention of sufficient residues, when compared to the common practices of heavy tillage before seeding, mono-cropping and crop residue removal [50]. Furthermore, reduced tillage practices combined with crop residue retention can increase moisture infiltration, reduce erosion and increase water use efficiency [51]. In this scenario, crop residues accumulating on the soil surface form a barrier to water loss through evaporation and decreased soil temperature [50]. In particular, the no-till method can improve soil organic matter content due to lower decomposition rates from the physical protection of carbon within aggregates [51-53], with a more stable soil aggregate structure being present under no-till compared to conventional tillage [54]. This maintenance of soil fertility is important for the high yield stability of crops and can be accomplished through catch crop cultivation with high biodiversity, a supply of organic matter as well as ploughless soil tillage. This is due to their positive effects on soil structure stability, the load-carrying capacity of the soil, humus content, soil organisms (e.g., Lumbircus terrestris) and microbial activity $[55,56]$. However, in this study, the predominant opinion of farmers and advisors was that reduced soil tillage or no-till systems had neutral or even negative effects on the yield stability of a wheat production system. Only with regards to climate change, the surveyed farmers and advisors commented in the free text fields that reduced soil tillage may be preferable for water-saving and reducing soil erosion. This is consistent with the findings of Falloon and Betts [57], where changes to the farmers in tillage practice under climate change focused mostly on soil water conservation and protection against soil erosion (both water and wind). Thus, a conspicuous discrepancy was obtained between the estimations of the farmers/advisors surveyed and the results of scientific studies presented above. One explanation may be that the positive effects of reduced soil tillage or no-till on yield stability would only be appreciated after a time-delay. A period of (at least) five years is often required before the advantages of the reduced tillage or no-till treatments resulted in higher and more stable yields when compared to conservative (intensive form) or conventional (plough) soil cultivation, although this happened only with residue retention [50]. On the other hand, Fuhrer and Chervet [56] specified that no-tillage systems with residue retention appeared to only have a marginal effect on the yield stability of winter wheat. In contrast, as a result of this study, conventional soil tillage and conservative soil cultivation (intensive and deep) was assumed to have positive effects on yield stability. These estimations have to be seen in the context that in Germany, 59\% of farmers are practicing conventional soil tillage and $40 \%$ conservative soil cultivation (intensive) so these are the most common used soil cultivation systems. Thus, only $1 \%$ of farmers are practicing no-tillsystems [58]. Therefore, a strong relationship of farmers' evaluation to positive effects on yield stability of winter wheat with the used soil cultivation system on their own farm has been found. We can conclude that the farmers surveyed are considering their used soil cultivation system to be the best option for yield stability. Additionally, farmers who do not use a practice are reluctant to make any positive statements about it. This can also be seen in the relatively high number of abstentions for no-till systems (Tables 6 and 7). Hence, further research is needed to assess the short- and long-term effects of soil cultivation systems on yield stability of wheat, other crops and different crop rotations. An integrative and practical approach would be of particular importance. Only this would enable farmers and advisors to derive valid personal evaluations about on-farm effects of soil cultivation on yield stability.

\subsection{Fertilization}

One major agronomic treatment used to reduce yield variability of cereal crops can be obtained by adequate fertilization of all relevant nutrients, with a focus on nitrogen fertilization [13,14]. This assessment was also shared by the respondents of this study. Farmers and advisors emphasized (in the free text field) the relevance of sufficient and well balanced macro- and micro-nutrient supply (N, P, K, S, Mn, Cu, Bor and $\mathrm{Zn}$ ) for wheat plants. They also highlighted the importance of straw manure for soil fertility and increasing the humus content in the soil. Through this, an improved water 
holding capacity of the soil can be reached so wheat plants may cope better with drought [57]. Soil organic matter is a key factor for agro-systems as it prevents soil degradation, reduces the risk of water pollution in addition to enhancing chemical, biological and physical soil properties [59]. Improvements to the soil organic matter content generally leads to an increase in agronomic productivity through better use of energy based inputs, including fertilizers, water andpesticides [60]. The use of organic fertilizer is considered an effective way of increasing soil organic carbon sequestration and supplying micro-nutrients to crops in comparison to the sole use of mineral fertilizers [61]. Furthermore, organic fertilization of wheat can lead to an increased grain yield of approximately $0.5 \mathrm{t} \mathrm{ha}^{-1}$ more than those only with mineral fertilizers, if nitrogen fertilization $\left(\mathrm{kg} \mathrm{N} \mathrm{ha}^{-1}\right)$ is on a comparable level [62]. Furthermore, organic fertilizers, especially manure either alone or in combination with mineral fertilizers, increases soil organic carbon as well as providing an effective means to conserve soil fertility and wheat production [63]. In terms of climate change, an increase of nutrient supply might be expected due to a longer vegetation period. However, more frequent heavy rainfall events may lead to a higher risk of nitrogen and phosphorous leaching, resulting in a need for fertilization and crop management modifications [30].

\subsection{Further Management Practices}

In comparison to other agronomic management practices, the effect of sowing date was ranked low by the farmers and advisors in this study, but still assumed a positive impact on the yield stability of wheat. The respondents commented that positive effects on yield stability could only be assumed if sowing date was adapted to site conditions and wheat cultivar. This ranking could be confirmed by related studies, while site, variety type and cultivar adapted sowing date could help to significantly improve yield stability of cereals $[13,64,65]$. Additionally, a few respondents mentioned that earlier sowing dates (mid-September) may lead to better root growth in autumn, which can improve the drought tolerance of wheat plants in the following spring. Earlier sowing dates are expected to use as much of the winter precipitation as possible, which can prolong the growing season. Thus, this allows the introduction of cultivars which have a longer development period [6]. On the other hand, earlier sowing also comes with risks, e.g., of increased virus and fungal disease pressure.

Irrigation is uncommon in German wheat production, which can be attributed to the high number of abstentions in this study (Tables 4 and 5). Furthermore, irrigation is only sometimes used on sandy soils or marginal sites, where wheat might not be the most preferable crop. Here, irrigation can be the decisive criterion and the only technique to obtain wheat yield. Under extreme unfavorable environmental conditions (e.g., soil and precipitation distribution), additional external input, such as water supply, gains importance. In terms of climate change, this aspect might lead to an increased use of irrigation in agronomic practice [4].

\section{Materials and Methods}

\subsection{Study Area}

In Germany, the agricultural area covers 16.7 million hectares, with arable farming on 11.8 million hectares by 276 thousand farms, which includes $8 \%$ organic and $92 \%$ conventional farming systems [1]. Here, winter wheat is the most important cereal crop and is currently grown on 3.2 million hectares, which is $60 \%$ of the winter cereal growing area [2]. In the harvest year of 2016, German wheat production was approximately 24.6 million tons with an average yield of $7.7 \mathrm{t} \mathrm{ha}^{-1}$ for winter wheat [66]. Thus, Germany is the second most important wheat producer (after France with 40 million tons) in the European Union [67]. The climate in Germany can be described as temperate with a long-term annual average air temperature of $8.9^{\circ} \mathrm{C}$ and long-term annual precipitation sum of $746 \mathrm{~mm}$ (spring: $178 \mathrm{~mm}$; summer: $231 \mathrm{~mm}$; autumn: $177 \mathrm{~mm}$; winter: $160 \mathrm{~mm}$ ) for the period 1981-2010 [68]. 


\subsection{Data Collection and Analysis}

The study was carried out nationwide in Germany from January-March 2017, based on a standardized, written survey. Farmers and advisors with experience in the field of wheat cultivation or research were invited as target groups to participate in the survey. The invitations for advisors were distributed as direct e-mails with a personal letter and a link to an online version of the survey. The invitations for farmers were send out via postal/fax mailings in cooperation with regional German farmer associations and the Regional Departments of Agriculture in addition to via personal invitations. In addition, short notes, articles and adverts in digital and print media (Agrarmagazin, Bauernzeitung, Agrarheute) advertised the survey. Here, a direct link to the Institute's webpage (University of Giessen, Professorship of Agronomy) was provided, where the online survey was placed on the home page.

First, participants were asked to provide general information about themselves, including field of work, experience in wheat cultivation (number of years). Additionally, farmers were asked about their farming system and site conditions (wheat acreage, soil and climate specifics). In the second part, the participants were asked eight questions about the yield stability of winter wheat covering the following issues: general importance of yield stability for wheat production, importance compared to yield amount, different agronomic management practices, soil cultivation system, comparison of different cultivars regarding variety type (hybrid vs. line) and registration year; and finally, the relevance of yield stable cultivars regarding climate change. The questions were in the form of closed questions (yes/no) and multiple choice questions with a single selection. A free text field for comments was provided next to each question.

At the end of the study, a total of 1022 (827 farmers and 195 advisors) questionnaires were collected (98 paper-based and 924 web-based surveys). In relation to the number of invitations this corresponds to an overall response rate of $71 \%$ for the advisors. The response rate for farmers was calculated based on wheat acreage. In this study, the farmers cultivated wheat on an average of 152 hectares per farm. Compared to the total wheat production area in Germany (3.15 million hectares), a response rate of $4 \%$ was calculated. With regards to the total number of farms in Germany (276 thousand), the response rate for farmers is $<1 \%$. After a review of each individual value with respect to reliability and coherence, 407 questionnaires needed to be excluded. This review contained the rejection of 315 questionnaires, because respondents only started the questionnaire or entered general information about themselves, but did not answer the disciplinary questions about yield stability of winter wheat. Additionally, 92 questionnaires were excluded, because the respondents stated to have no experience in wheat production (zero years), made only non-relevant answers (statements on agriculture in general) or entered non-reliable values (e.g., wheat acreage = one million hectare). Thus, a sample size of 615 questionnaires (farmers 474 and 141 advisors) formed the data for this study. Sociodemographic details of this study with regards to regional distribution, annual wheat acreage and experience in wheat production of the participant group 'farmers' are shown in Table 12. For the advisors surveyed, an average experience in wheat production of 17 years can be stated. The advisors interviewed are often working in more than one region or nationwide in Germany. Thus, detailed information about the regional distribution of participant group 'advisors' is not shown here.

Table 12. Sociodemographic details of participant group 'farmers' with regard to regional distribution, annual wheat acreage and experience in wheat production.

\begin{tabular}{cccc}
\hline $\begin{array}{c}\text { Region in } \\
\text { Germany }\end{array}$ & $\begin{array}{c}\text { Number of } \\
\text { Participants }(\boldsymbol{n})\end{array}$ & $\begin{array}{c}\text { Average Annual Wheat } \\
\text { Acreage (ha) }\end{array}$ & $\begin{array}{c}\text { Average Experience in Wheat } \\
\text { Production (years) }\end{array}$ \\
\hline North & 109 & 21 & 13 \\
South & 78 & 15 & 10 \\
East & 132 & 83 & 12 \\
West & 84 & 17 & 10 \\
Central & 71 & 22 & 16 \\
\hline
\end{tabular}


The descriptive analysis and the calculation of correlation coefficients (association between various responses/questions) were made with IBM SPSS Statistics 23 software (IBM Corporation, New York, NY, USA). Additionally, a small number of participants made comments in the free text fields. These comments are mentioned next to the related issues and tables in chapters of results and discussion.

It should be noted critically that the results only provide subjective estimations of the respondents and are not generally valid due to limited statistical representativeness. In web-based surveys, there is often a problem in defining the sampling frames [69]. Furthermore, the testing environments are not transparent for the interviewer, while there are also problems with high drop-out rates, non-reliable or multiple answers [70]. To prevent these issues, each questionnaire was checked for reliability and multiple entries were prevented through technical restrictions (e.g., single filling per ID address). Additionally, the target group of farmers and advisors were invited by farmer's associations and even personally by the interviewer herself via announcements in agricultural magazines and websites. Thus, the participants were clearly targeted. The comparison of responses from web-based and paper based surveys showed the following. There was a high dropout rate in online questionnaires (online survey clicked on 1357 times with participants beginning to fill out, but only 924 received back). In contrast, nearly all farmers and advisors filled-out paper based surveys and sent back the questionnaire (sent out 109 and received back 98). Additionally, from the total of 1022 received questionnaires, the web-based survey needed to be omitted for evaluation more often than paper based ones, because the respondents stopped filling out after the general information section at the beginning or even made inadequate comments, but gave no serious answers at all (rejection rate: in total 407, web-based 386, paper-based 21). Regarding the questionnaires evaluated $(n=615)$, no differences between the responses from web-based and paper-based surveys could be determined. Overall, the advantages of a web-based empirical study attaining a large target group by a single interviewer and providing a broad-based data set outweigh the possible risks as above-mentioned.

\section{Conclusions}

Yield stability of winter wheat is of major importance in agronomic practice and seems to be more important than the yield amount, especially when considering climate change. However, yield stability is a complex subject and can be affected by many environmental, genetic and agronomic factors. Hence, yield stability in farming practice must be seen and improved in a systems approach. However, even if environmental conditions are uncontrollable, farmers can adapt their agronomic management practices. To enable this change, further research effort is needed. Initial approaches are shown by current wheat breeding projects. New wheat cultivars, especially promising hybrid candidates, provide favorable combinations of high yield stability and high yield amount. Furthermore, official variety testing under a wide range of environmental conditions (soil, year) and agronomical management practices with valid estimations of yield stability is necessary. However, wheat breeding and cultivar choice are not the only methods for improving yield stability. To think in an agronomic systems approach, favorable and diverse crop rotations, site adapted soil cultivation systems, integrated plant protection, appropriate mineral and organic fertilization in additions optimal seeding conditions in autumn are the foundations for improving the yield stability of winter wheat. All these individual sub-sectors should complement each other and work well as a whole. Thus, further investigation should not only focus on specific or single issues, but on a larger scale in a comprehensive systems approach to better understand the environmental and agronomic interaction effects on the long-term yield stability of winter wheat. Estimations of yield stability should be confirmed by multi-environmental field trials for winter wheat, which implies testing over several years and at several locations with different soil conditions. Therefore, to achieve this goal, long-term field trials in diverse growing regions are essential to provide valid estimations about the interaction effects of environmental conditions and different agronomic management practices (e.g., crop rotation, soil cultivation, fertilization, cultivar and plant protection) on the yield stability of winter wheat. Furthermore, these results should be proven if there might be any differences regarding yield stability of winter wheat between conventional 
and biological farming practices. Overall, this implies the need for the use of high personnel and monetary resources for broad field testing. However, the study would be of great worth and potential value. Thus, research cooperation for an exchange of experience and results as well as for retrospective secondary stability-analysis of multi-environments could be an option.

Acknowledgments: We acknowledge funding to cover the costs of publishing with open access by the Justus-Liebig-University Giessen.

Author Contributions: J.M. and B.H. conceived and designed the experiments; J.M. performed the experiments and analyzed the data; J.M. and B.H. discussed the results; and J.M. wrote the paper.

Conflicts of Interest: The authors declare no conflict of interest. The founding sponsors had no role in the design of the study; in the collection, analyses, or interpretation of data; in the writing of the manuscript, and in the decision to publish the results.

\section{References}

1. Destatis. Available online: https://www.destatis.de/DE/ZahlenFakten/ Wirtschaftsbereiche/LandForstwirtschaftFischerei/LandwirtschaftlicheBetriebe/Tabellen/ LandwirtschaftlicheBetriebeFlaechenHauptnutzungsarten.html (accessed on 25 April 2017).

2. Destatis. Available online: https://www.destatis.de/DE/PresseService/Presse/Pressemitteilungen/2016/ 12/PD16_470_412.html (accessed on 25 April 2017).

3. Macholdt, J.; Honermeier, B. Impact of climate change on cultivar choice. Adaptation strategies of farmers and advisors in German cereal production. Agronomy 2016, 6, 40. [CrossRef]

4. Wiebe, K.; Lotze-Campen, H.; Sands, R.; Tabeau, A.; van der Mensbrugghe, D.; Biewald, A.; Bodirsky, B.; Islam, S.; Kavallari, A.; Mason-D'Croz, D.; et al. Climate change impacts on agriculture in 2050 under a range of plausible socioeconomic and emission scenarios. Environ. Res. Lett. 2015, 10, 85010. [CrossRef]

5. Pompe, S.; Hanspach, J.; Badeck, F.; Klotz, S.; Thuiller, W.; Kühn, I. Climate and land use change impacts on plant distributions in Germany. Biol. Lett. 2008, 4, 564-567. [CrossRef] [PubMed]

6. Crane, T.A.; Roncoli, C.; Hoogenboom, G. Adaptation to climate change and climate variability: The importance of understanding agriculture as performance. Wageningen J. Life Sci. 2011, 57, 179-185. [CrossRef]

7. Parry, M.A.J.; Hawkesford, M.J. An integrated approach to crop genetic improvement. J. Integr. Plant Biol. 2012, 54, 250-259. [CrossRef] [PubMed]

8. Stratonovitsch, P.; Semenov, M.A. Heat tolerance around flowering in wheat identified as a key trait for increased yield potential in Europe under climate change. J. Exp. Bot. 2015, 66, 3599-3609. [CrossRef] [PubMed]

9. Mühleisen, J.; Piepho, H.P.; Maurer, H.P.; Longin, C.F.H.; Reif, J.C. Yield stability of hybrids versus lines in wheat, barley, and triticale. Theor. Appl. Gen. 2014, 127, 309-316. [CrossRef] [PubMed]

10. Macholdt, J.; Barthelmes, G.; Ellmer, F.; Baumecker, M. Yield stability of winter wheat grown in Brandenburg. J. Cultiv. Plants 2013, 65, 411-421.

11. Michel, V.; Zenk, A. Suitability of winter wheat varieties under specific growing conditions and introduction of new parameters for evaluation of varieties with special consideration for climate change. German Research Institute of Agriculture and Fisheries Mecklenburg-Vorpommern (Gülzow). Available online: http://www.landwirtschaft-mv.de/cms2/LFA_prod/LFA/content/de/Fachinformationen/Sorten/ weitere_Artikel_und_Vortraege/index.jsp?\&seite=3\&artikel=2993 (accessed on 25 April 2017).

12. Hejcman, M.; Kunzová, E.; Srek, P. Sustainability of winter wheat production over 50 years of crop rotation and N, P and K fertilizer application on illimerized luvisol in the Czech Republic. Field Crops Res. 2010, 139, 30-38. [CrossRef]

13. Macholdt, J.; Honermeier, B. Impact of highly varying seeding densities on grain yield and yield stability of winter rye cultivars under the influence of delayed sowing under sandy soil conditions. Arch. Agron. Soil Sci. 2017. [CrossRef]

14. Varvel, G.E. Crop rotation and nitrogen effects on normalized grain yield in a long-term study. Agron. J. 2000, 92, 938-941. [CrossRef]

15. Berzsenyi, Z.; Györffy, B.; Lap, D.C. Effect of crop rotation and fertilization on maize and wheat yields and yield stability in a long-term experiment. Eur. J. Agron. 2000, 13, 225-244. [CrossRef] 
16. Christen, O. Yield, yield structure and yield stability of wheat, barley and oilseed rape in different crop rotations. Pflanzenbauwissenschaften 2001, 5, 33-39.

17. Sieling, K.; Christen, O. Crop rotation effects on yield of oilseed rape, wheat and barley and residual effects on the subsequent wheat. Arch. Agron. Soil Sci. 2015, 61, 1531-1549. [CrossRef]

18. Coromaldi, M.; Pallante, G.; Savastanoet, S. Adoption of modern varieties, farmers' welfare and crop biodiversity: Evidence from Uganda. Ecol. Econ. 2015, 119, 346-358. [CrossRef]

19. Gaudin, A.C.M.; Tolhurst, T.N.; Ker, A.P.; Janovicek, K.; Tortora, C.; Martin, R.C.; Deen, W. Increasing crop diversity mitigates weather variations and improves yield stability. PLoS ONE 2015, 10, e0113261. [CrossRef] [PubMed]

20. Rial-Lovera, K.; Davies, W.P.; Cannon, N.D. Implications of climate change predictions for UK cropping and prospects for possible mitigation: A review of challenges and potential responses. J. Sci. Food Agric. 2017, 97, 17-32. [CrossRef] [PubMed]

21. Becker, H.C.; Leon, J. Stability analysis in plant breeding. Plant Breed. 1988, 101, 1-23. [CrossRef]

22. Piepho, H.P. Methods for comparing the yield stability of cropping systems-A review. J. Agron. Crop Sci. 1998, 180, 193-213. [CrossRef]

23. Reidsma, P.; Ewert, F.; Lansink, A.O.; Leemans, R. Adaptation to climate change and climate variability in European agriculture: The importance of farm level responses. Eur. J. Agron. 2010, 32, 91-102. [CrossRef]

24. Gornott, C.; Wechsung, F. Statistical regression models for assessing climate impacts on crop yields: Avalidation study for winter wheat and silage maize in Germany. Agric. For. Meteorol. 2016, 217, 89-100. [CrossRef]

25. Montesino-San Martína, M.; Olesen, J.E.; Porter, J.R. A genotype, environment and management (GxExM) analysis of adaptation in winter wheat to climate change in Denmark. Agric. For. Meterol. 2014, 187, 1-13.

26. German Federal Ministry of Food and Agriculture. Price volatility. Available online: https://www.bmel.de/ EN/Agriculture/Market-Trade-Export/_Texte/Preisvolatilitaet.html (accessed on 25 April 2017).

27. Eitzinger, J.; Kersebaum, K.C.; Formayer, H. Landwirtschaft im Klimawandel; AgriMedia: Clenze, Germany, 2009; pp. 276-288.

28. Rozbicki, J.; Ceglinska, A.; Gozdowski, D.; Jakubczak, M.; Cacak-Pietrzak, G.; Madry, W.; Golba, J.; Sobczynski, G.; Studnicki, M.; Drzaga, T. Influence of the cultivar, environment and management on the grain yield and bread-making quality in winter wheat. J. Cereal Sci. 2015, 61, 126-132. [CrossRef]

29. Bilgin, O.; Guzman, C.; Baser, I.; Crossa, J.; Korkut, K.Z. Evaluation of grain yield and quality traits of bread wheat genotypes cultivated in Northwest Turkey. Crop Sci. 2015, 56, 73-84. [CrossRef]

30. Olesen, J.E.; Trnka, M.; Kersebaum, K.C.; Skjelvag, A.O.; Seguin, B.; Peltronen-Sainio, P.; Rossi, F.; Kozyra, J.; Micale, F. Impacts and adaptation of European crop production systems to climate change. Eur. J. Agron. 2011, 34, 96-112. [CrossRef]

31. Loyce, C.; Meynard, J.M.; Bouchard, C.; Rolland, B.; Lonnet, P.; Bataillon, P.; Bernicot, M.H.; Bonnefoy, M.; Charrier, X.; Debote, B.; et al. Growing winter wheat cultivars under different management intensities in France: A multicriteria assessment based on economic, energetic and environmental indicators. Field Crops Res. 2012, 125, 167-178. [CrossRef]

32. Laidig, F.; Piepho, H.P.; Drobek, T.; Meyer, U. Genetic and non-genetic long-term trends in 12 different crops in German official variety performance trials an on-farm yield trends. Theor. Appl. Genet. 2014, 127, 2599-2617. [CrossRef] [PubMed]

33. Mackay, I.; Horwell, A.; Garner, J.; White, J.; McKee, J.; Philpott, H. Reanalyses of the historical series of UK variety trials to quantify the contributions of genetic and environmental factors to trend and variability in yield over time. Theor. Appl. Genet. 2011, 122, 225-238. [CrossRef] [PubMed]

34. Laidig, F.; Piepho, H.P.; Rentel, D.; Drobek, T.; Meyer, U.; Huesken, A. Breeding progress, environmental variation and correlation of winter wheat yield and quality traits in German official variety trials and on-farm during 1983-2014. Theor. Appl. Genet. 2017, 130, 223-245. [CrossRef] [PubMed]

35. Oritz, R.; Wagoire, W.W.; Hill, J.; Chandra, S.; Madsen, S.; Stolen, O. Heritability of correlations among genotype-by-environment stability statistics for grain yield in bread wheat. Theor. Appl. Genet. 2001, 103, 469-474. [CrossRef]

36. Federal Plant Variety Office. Descriptive Variety List 2016. Available online: https:/ /www.bundessortenamt. de/internet30/fileadmin/Files/PDF/bsl_getreide_2016.pdf (accessed on 25 April 2017). 
37. Saaten Union Hybrid wheat cultivars. Available online: http:/ /www.saaten-union.de/index.cfm/article/ 1055.html (accessed on 20 April 2017).

38. Longin, C.F.H.; Mühleisen, J.; Maurer, H.P.; Zhang, H.; Gowda, M.; Reif, J.C. Hybrid breeding in autogamous cereals. Theor. Appl. Genet. 2012, 125, 1087-1096. [CrossRef] [PubMed]

39. Finckh, M.R. Integration of breeding and technology into diversification strategies for disease control in modern agriculture. Eur. J. Plant Pathol. 2008, 121, 399-409. [CrossRef]

40. Grover, K.K.; Karsten, H.D.; Roth, G.W. Corn grain yields and yield stability in four long-term cropping systems. Agron. J. 2009, 101, 940. [CrossRef]

41. Shrestha, B.M.; McConkey, B.G.; Smith, W.N.; Desjardins, R.L.; Campbell, C.A.; Grant, B.B.; Miller, P.R. Effects of crop rotation, crop type and tillage on soil organic carbon in a semiarid climate. Can. J. Soil Sci. 2013, 93, 137-146. [CrossRef]

42. Karlen, D.L.; Varvel, D.E.; Bulldock, D.G.; Cruse, R.M. Crop rotation for the 21st century. Adv. Agron. 1994, $53,1-45$.

43. German Federal Ministry of Food and Agriculture. Governmental fertilization regulations. Available online: http:/ / www.bmel.de/SharedDocs/Reden/2017/16-02-FL-DuengegesetzBT.html (accessed on 18 April 2017).

44. German Federal Ministry of Food and Agriculture. German governmental Plant Protection Act. Available online: https://www.bmel.de/DE/Landwirtschaft/Pflanzenbau/Pflanzenschutz/_Texte/ Pflanzenschutzbestimmungen.html (accessed on 18 April 2017).

45. Bertelsen, J.R.; de Neergaard, E.; Smedegaard-Petersen, V. Fungicidal effects of azoxystrobin and epoxiconazole on phylloshere fungi, senescence and yield of winter wheat. Plant Pathol. 2001, 50, 190-205. [CrossRef]

46. Mercer, P.C.; Ruddock, A. Disease management of winter wheat with reduced doses of fungicides in Nothern Ireland. Crop Prot. 2005, 24, 221-228. [CrossRef]

47. Loyce, C.; Meynard, J.M.; Bouchard, C.; Rolland, B.; Lonnet, P.; Bataillon, P.; Bernicot, M.H.; Bonnefoy, M.; Charrier, X.; Debote, B.; et al. Interaction between cultivar and crop management effects on winter wheat diseases, lodging, and yield. Crop Prot. 2008, 27, 1131-1142. [CrossRef]

48. De Vallavielle-Pope, C. Management of disease resistance diversity of cultivars of a species in single fields: Controlling epidemics. Plant Biol. Pathol. 2004, 327, 611-620. [CrossRef]

49. Mille, B.; deVallavielle-Pope, C. Cultivar mixtures and fungicide sprays against leaf and glume blotch and brown rust in winter wheat. Cah. Agric. 2001, 10, 125-129.

50. Govaerts, B.; Sayre, K.D.; Deckers, J. Stable grain yields with zero tillage and permanent bed planting. Field Crops Res. 2005, 94, 33-42. [CrossRef]

51. McGarry, D. Conservation Agriculture Practices for Sustainable Cotton Production, Through Improved Soil Structure and Increased Water Use Efficiency. In Proceedings of the International Workshop on Conservation Agriculture for Sustainable Wheat Production in Rotation with Cotton in Limited Water Resource Areas, Tashkent, Uzbekistan, 14-18 October 2002.

52. Busari, M.A.; Kukai, S.S.; Kaur, A.; Bhatt, R.; Dulazi, A.A. Conservation tillage impacts on soil, crop and the environment. Int. Soil Water Conserv. Res. 2015, 3, 119-129. [CrossRef]

53. Six, J.; Elliott, E.T.; Paustian, K. Soil macroaggregate turnover and microaggregate formation: A mechanism for C sequestration under no-tillage agriculture. Soil Biol. Biochem. 2000, 32, 2099-2103. [CrossRef]

54. Limon-Ortega, A.; Sayre, K.D.; Drijber, R.A.; Francis, C.A. Soil attributes in a furrow-irrigated bed planting system in northwest Mexico. Soil Tillage Res. 2002, 63, 123-132. [CrossRef]

55. Stadler, M. Wie die Bodenfruchtbarkeit erhalten und verbessern? Getreidemagazin 2017, 2, 61-63.

56. Fuhrer, J.; Chervet, A. No-tillage: Long-term benefits for yield stability in a more variable climate. Prot. Environ. Sci. 2015, 29, 194-195. [CrossRef]

57. Falloon, P.; Betts, R. Climate impacts on European agriculture and water management in the context of adaptation and mitigation-The importance of an integrated approach. Sci. Total Environ. 2010, 23, 5667-5687. [CrossRef] [PubMed]

58. Destatis. Available online: https://www.destatis.de/DE/ZahlenFakten/Wirtschaftsbereiche/ LandForstwirtschaftFischerei/Landwirtschaftszaehlung2010/Tabellen/8_1_Bodenbearbeitungsverfahren. html (accessed on 5 June 2017).

59. Stumpe, H.; Wittenmayer, L.; Merbach, W. Effects and residual effects of straw, farmyard manuring, and mineral fertilization at Field F of the long-term trial in Halle (Saale), Germany. J. Plant Nutr. Soil Sci. 2000, 163, 649-656. [CrossRef] 
60. Lal, R. Sequestering carbon in soils of agro-ecosystems. Food Policy 2011, 36, 33-39. [CrossRef]

61. Lal, R. Challenges and opportunities in soil organic matter research. Eur. J. Soil Sci. 2009, 60, 158-169. [CrossRef]

62. Maltas, A.; Oberholzer, H.; Charles, R.; Sinaj, S. Effet a long terme des engrais organiques sure les properietes du sol. Rech. Agron. Suisse 2012, 3, 148-155.

63. Manna, M.C.; Swarup, A.; Wanjari, R.H.; Mishra, B.; Shahi, D.K. Long-term fertilization, manure and lining effects on soil organic matter and crop yields. Soil Tillage Res. 2007, 94, 397-409. [CrossRef]

64. Schwarte, A.J.; Gibson, L.R.; Karlen, D.L.; Liebman, M.; Jannink, J.L. Plantind date effects on winter triticale dry matter and nitrogen accumulation. Agron. J. 2005, 97, 1333-1341. [CrossRef]

65. Lawson, A.; Cogger, C.; Bary, A.; Fortuna, A.M. Influence of seeding ratio, planting date, and termination date on rye-hairy vetch cover crop mixture performance under organic management. PLoS ONE 2015, 10, e0129597. [CrossRef] [PubMed]

66. German Federal Statistical Office-Destatis. German wheat production area and annual wheat yield. Available online: https://www.destatis.de/DE/ZahlenFakten/Wirtschaftsbereiche/LandForstwirtschaftFischerei/ FeldfruechteGruenland/Tabellen/FeldfruechteZeitreihe.html (accessed on 25 April 2017).

67. Eurostat. Agriculture, forestry and fishery statistics-2016 edition. Available online: http:/ /ec.europa.eu/ eurostat/documents/3217494/7777899/KS-FK-16-001-EN-N.pdf (accessed on 25 April 2017).

68. German Federal Ministry of Transport and Digital Infrastructure, German Weather Service. German Climate atlas. Available online: http://www.dwd.de/DE/leistungen/klimadatendeutschland/langj_mittelwerte. html (accessed on 30 May 2017).

69. Couper, M. Web surveys: A review of issues and approaches. Public Opin. Q. 2000, 64, 464-494. [CrossRef] [PubMed]

70. Gosling, S.D.; Vazire, S.; Srivastava, S.; John, O.P. Should we trust web-based studies? A comparative analysis of six preconceptions about internet questionnaires. Am. Psychol. 2004, 59, 93-104. [CrossRef] [PubMed]

(C) 2017 by the authors. Licensee MDPI, Basel, Switzerland. This article is an open access article distributed under the terms and conditions of the Creative Commons Attribution (CC BY) license (http:// creativecommons.org/licenses/by/4.0/). 